\title{
Arasturma
}

\section{The Effects of Undiagnosed Nocturnal Hypoxia on the Intensive Care Unit Admission Scores}

\author{
Bülent GÜÇYETMEZ, Hakan Korkut ATALAN, Nahit ÇAKAR
}

\section{ABSTRACT}

Objective: Undiagnosed obstructive sleep apnea syndrome (OSAS) which is characterized with nocturnal hypoxia (NH) is commonly seen in population. Furthermore, it is associated with postoperative complications, prolonged hospital stay and nocturnal death. Hence, in this study, it was aimed to investigate the effects of undiagnosed NH on the ICU admission scores.

Material and Methods: This study was designed as a prospective observational study. Sleep apnea test (SAT) was performed on 64 patients with the diagnosis of pneumonia at the 6th month after hospital discharge. Demographic data, ICU admission scores, length of hospital stay, apnea-hypopnea index (AHI), minimum $\mathrm{SpO}_{2}\left(\mathrm{~min}-\mathrm{SpO} \mathrm{O}_{2}\right)$, percentage of $\mathrm{NH}(\mathrm{NH} \%)$, minimum and maximum heart rates were recorded.

Results: For all patients, the median values of APACHE II score, Charlson comorbidity index (CCI), AHI, min$\mathrm{SpO}_{2}, \mathrm{NH} \%, \max -\mathrm{HR}$ and length of hospital stay were $18,5,21.5,78 \%, 33.2 \%, 121 \mathrm{~min}^{-1}$, and 11 days. $\mathrm{NH} \%$ was positively correlated with APACHE II score, CCI and length of hospital stay. In patients with $\mathrm{NH} \% \geq 18 \%$, while CCI, APACHE II, AHI, max-HR, length of ICU and hospital stay were significantly higher; $\min -\mathrm{SpO}_{2}$ was significantly lower than patients with $\mathrm{NH} \%<18 \%$. In multivariate analysis, length of hospital stay increased by each unit increase in CCI, APACHE II score and $\mathrm{NH} \%$.

Conclusion: Most of the patients admitted to the ICU can have undiagnosed NH. Increase in NH\% may be a reason for increased ICU admission scores and prolonged hospital stay.

Keywords: nocturnal hypoxia, APACHE II score, apnea-hypopnea index

Alındığı tarih: 21.06 .2017

Kabul tarihi: 22.06.2017

Acıbadem Üniversitesi Anesteziyoloji ve Reanimasyon Ana Bilim Dalı

Yazışma adresi: Uzm. Dr. Bülent Güçyetmez, Kerem Aydınlar Kampüsü Kayışdağı Cad. No: 32 Ataşehir 34752 İstanbul e-mail: bulentgucyetmez@gmail.com
öZ

Tanısı Konulmamış Gece Hipoksisinin Yoğun Bakım Giriş Skorlart $\ddot{U}$ zerine Etkileri

Amaç: Gece hipoksisi (GH) ile karakterize olan tanısı konulmamış obstrüktif uyku apnesi sendromu (OUAS) toplumda sık görülmektedir. Ayrıca, postoperatif komplikasyonlar, uzamış hastane kalış süresi ve gece ölümü ile ilişkilidir. Bu nedenle, bu çalışmada tanısı konulmamış GH'nin yoğun bakım giriş skorları üzerine etkilerinin araştırılması amaçlanmıştır.

Gereç ve Yöntem: Çalışma prospektif gözlemsel olarak dizayn edilmiştir. Çalışmaya dahil edilen 64 pnömoni tanılı hastaya hastaneden taburcu olduktan 6 ay sonra uyku apnesi testi (UAT) uygulanmıştır. Demografik veriler, yoğun bakım giris skorları, hastane kalış süresi, apnea-hipopne indeksi (AHI), minimum periferik oksijen satürasyonu (min-SpO $\left.{ }_{2}\right), G H$ yüzdesi (\%GH), minimum ve maksimum kalp hızı kaydedilmiştir.

Bulgular: Tüm hastaların APACHE II skoru, Charlson comorbidity indeksi (CCI), AHI, min-SpO,$\%$ GH, maksimum kalp hızı ve hastane kalış süresi median değerleri $18,5,21.5, \% 78, \% 33.2,121 d k^{-1}$ ve 11 'di. \%GH ile APACHE II skoru, CCI ve hastane kalıs süresi arasında pozitif korelasyon vardl. $\% G H \geq \% 18$ olan hastalarda CCI, APACHE II skoru, maksimum kalp hiz,, yoğun bakım ve hastane kalış süreleri anlaml yüksek; min$\mathrm{SpO}_{2}$ anlamlı düşük bulundu. Çok değişkenli analizde, CCI, APACHE II skoru ve \%GH'deki her bir birim artış hastane kalış süresini arttırd.

Sonuç: Yoğun bakıma alınan hastaların önemli bir kısmı yoğun bakım girişinde tanısı konulmamış GH'ye sahip olabilirler. \%GH'deki artış, artmıs yoğun bakım giriş skorları ve uzamış hastane kalış süresi için bir neden olabilir.

Anahtar kelimeler: gece hipoksisi, APACHE II skoru, apne-hipopne indeksi 


\section{INTRODUCTION}

Hypoxia is related to the organ dysfunction which leads to a decrease in the delivery of oxygen $\left(\mathrm{DO}_{2}\right)$ ${ }^{[1,2]}$. Obstructive sleep apnea syndrome (OSAS) which is characterized with nocturnal hypoxia $(\mathrm{NH})$ is also associated with hypertension, diabetes mellitus, atrial fibrillation, pulmonary hypertension, postoperative complications, prolonged hospital stay and nocturnal death because of chronic nocturnal hypoxia ${ }^{[3-9]}$. Moreover, OSAS is known to have a high prevalence in population, and a significant amount of these cases are undiagnosed OSAS ${ }^{[10]}$. According to 2009 Guidelines, apnea hypopnea index (AHI) is a diagnostic parameter for OSAS and it is determined by performing polysomnography ${ }^{[11]}$. Nevertheless, in the guideline, portable monitors (PMs) are also defined as monitors which record $\mathrm{AHI}$, minimum-peripheral oxygen saturation $\left(\min -\mathrm{SpO}_{2}\right)$ and duration of $\mathrm{SpO}_{2} \leq 90 \%$ ${ }^{[11,12]}$. Ambulatory monitorization have been already performed in different clinical situations during ICU (intensive care unit) stay ${ }^{[13]}$. $\mathrm{NH}$ can also be directly determined based on the duration of $\mathrm{SpO}_{2} \leq 90 \%$ by using PMs. In the present study, our hypothesis was that being in a situation of undiagnosed $\mathrm{NH}$ in daily sleep period before ICU admission can be associated with the ICU admission scores.

\section{MATERIALS and METHODS}

\section{Study design}

Upon the approval of Acrbadem University Ethic Committee (ATADEK), the present study was designed as a prospective observational study. All patients with pneumonia admitted to the ICU between June 1st 2014, and June 1 st 2015 were evaluated. Patients who were $<18$-year old, non-survivor patients, cases with diagnosis of trauma, chronic obstructive pulmonary disease (COPD), congestive heart failure, cerebrovascular disease, cancer and tracheotomized patients were excluded. Sixty-four patients with pneumonia who were included in the study were called back in the $6^{\text {th }}$ month after hospital discharge. After their consent was obtained, sleep apne test (SAT) was performed in a special room by using PM (ApneaLinkTM, RESMED-Munich, Germany). All NH parameters such as $\mathrm{AHI}$, min- $\mathrm{SpO}_{2}$, duration of $\mathrm{SpO}_{2} \leq 90 \%$ were recorded during sleep period by
ApneaLinkTM. In the morning of the day after, ApneaLinkTM software Version 7.0.

\section{Database}

In the ICU period, the patient's age (years), gender, body mass index (BMI) $\left(\mathrm{kg} \mathrm{m}^{-2}\right)$, APACHE II (Acute Physiology and Chronich Health Evaluation) score, Charlson comorbidity index (CCI), clinic pulmonary infection score (CPIS), isolated microorganisms identified, norepinephrine, steroid, invasive mechanical ventilation (IMV) and renal replacement therapy (RRT) requirements, length of ICU and hospital stay (days) were recorded. During application of SAT, patients' duration of SAT (minute), AHI $\left(\mathrm{h}^{-1}\right)$, min- $\mathrm{SpO}_{2}$ (\%), duration of $\mathrm{SpO}_{2} \leq 90 \%$ (minute), the percentage of $\mathrm{NH}(\mathrm{NH} \%)$, minimum and maximum heart rate (min-HR and max-HR) were also recorded.

\section{Definitions}

According to Adult Obstructive Sleep Apnea Task Force of the American Academy of Sleep Medicine, a PM should include an oronasal thermal sensor to detect apneas, a nasal pressure transducer to measure hypopneas; oximetry and inductance plethysmography to record the respiratory effort ${ }^{[11}$. The ApneaLinkTM (RESMEDMunich, Germany) is a PM which can measure, and record AHI, min- $\mathrm{SpO}_{2}$, duration of $\mathrm{SpO}_{2} \leq 90 \%$, minimum and maximum HR during sleep ${ }^{[12]}$.

The SAT was defined as a sleep test which NH markers could be recorded by using PM. Apnea was a non-breathing period lasting over 10 seconds. Hypopnea was defined as a breathing period with a $50 \%$ decrease in amplitude and a more than $4 \%$ decrease in oxygen saturation ${ }^{[11]}$. Min- $\mathrm{SpO}_{2}$ was the lowest saturation during the application of SAT. The duration of $\mathrm{SpO}_{2} \leq 90 \%$ was the sum of the $\mathrm{SpO}_{2} \leq 90 \%$ periods during the application of SAT. The $\mathrm{NH} \%$ was defined as the ratio between the duration of $\mathrm{SpO}_{2} \leq 90 \%$ and the SAT application time (duration of $\mathrm{SpO}_{2} \leq 90 \% \div$ duration of SAT).

\section{Statistical analysis}

Statistical analysis was performed with the Wizard Pro Version 1.7.20. All of the variables in the database were summarized by using descriptive statistics. The 
results were given as the percentage (\%) and median (quartiles). All variables were tested for normal distribution using Kolmogorov-Simirnov test. Pearson correlation test was performed to determine the correlations and expressed as $\mathrm{r} 2$. According to the first quartile of $\mathrm{NH} \%$, two $\mathrm{NH} \%$ groups were defined and Student-t and Mann-Whitney U tests were used for the comparison between $\mathrm{NH} \%$ groups. The multivariate regression model included age, BMI, APACHE II score, $\mathrm{CCI}, \mathrm{AHI}, \mathrm{min}-\mathrm{SpO}_{2}$ and $\mathrm{NH} \%$ to estimate an increase in the length of hospital stay. These parameters were added to the regression model by using enter method. A type 1 error was established at 0.05 .

\section{RESULTS}

Sixty-four patients with pneumonia were included in this study. For all patients, the median values of age, APACHE II, CCI, AHI, min- $\mathrm{SpO}_{2}, \mathrm{NH} \%$, maxHR, length of hospital stay were $69,18,5,21.5$, $78 \%, 33.2 \%, 121 \mathrm{~min}^{-1}$, and 11 days, respectively (Table 1). The first quartile of NH\% was $18 \%$ (Table 1). In patients with $\mathrm{NH} \% \geq 18 \%$, CCI, APACHE II, AHI, max-HR and length of hospital stay were significantly higher; min- $\mathrm{SpO}_{2}$ was significantly lower than patients with $\mathrm{NH} \%<18 \%$ (Table 2). $\mathrm{NH} \%$ was positively correlated with APACHE II, CCI and length of hospital stays $(\mathrm{r} 2=0.16 ; \mathrm{r} 2=0.26 ; \mathrm{r} 2=0.43$ respectively, $\mathrm{p}<0.001$ for all) (Figure 1). In multivariate analysis, length of hospital stay was increased by an increase in CCI, APACHE II and $\mathrm{NH} \%(\mathrm{p}=0.015$; $\mathrm{p}<0.001 ; \mathrm{p}=0.012$, respectively) (Table 3 ).

\section{DISCUSSION}

This is the first study which the effects of undiagnosed $\mathrm{NH}$ on critically ill patients were evaluated. The present study showed that undiagnosed $\mathrm{NH}$ in daily sleep period was associated with higher ICU admission scores and poor outcomes.

It is known that all tissues use NADH for the production of mitochondrial energy which precipitates the need for oxygen ${ }^{[1,2]}$. Hence, hypoxia should be directly related to the organ dysfunction via delivery of oxygen because if the oxygen saturation decreases, $\mathrm{DO}_{2}$ also decreases ${ }^{[14]}$. In recent studies, it was already demonstrated that $\mathrm{NH}$ was associated with morbidity and mortality ${ }^{[3,4,15]}$. In this study, the most important
Table 1. Demographic data, outcomes and apnea test markers.

\begin{tabular}{|c|c|}
\hline \multicolumn{2}{|l|}{ Demographic data } \\
\hline Age, (years) & $69(65-78)$ \\
\hline Male, $\mathrm{n}(\%)$ & $44(68.8)$ \\
\hline BMI, $\left(\mathrm{kg} \mathrm{m}^{-2}\right)$ & $28(26.4-0.1)$ \\
\hline $\mathrm{CCI}$ & $5(4-6)$ \\
\hline APACHE II & $18(14-24)$ \\
\hline CPIS & $7(7-8)$ \\
\hline \multicolumn{2}{|l|}{ Microorganisms, $n(\%)$} \\
\hline Klebsiella pneumonia & $18(28.1)$ \\
\hline Streptococcus pneumonia & $14(21.9)$ \\
\hline Enterococcus & $10(15.6)$ \\
\hline Candida albicans & $9(14.1)$ \\
\hline Non-albicans candida & $5(7.8)$ \\
\hline E. coli & $3(4.7)$ \\
\hline Unidentified & $5(7.8)$ \\
\hline \multicolumn{2}{|l|}{ Medications and supports, $\boldsymbol{n}(\%)$} \\
\hline The usage of norepinephrine & $27(42.2)$ \\
\hline IMV requirement & $22(34.4)$ \\
\hline The usage of steroid & $20(31.3)$ \\
\hline RRT requirement & $4(6.3)$ \\
\hline \multicolumn{2}{|l|}{ Outcomes } \\
\hline Length of ICU stay, (day) & $6(4-8)$ \\
\hline Length of hospital stay, (day) & $11(8-13)$ \\
\hline \multicolumn{2}{|l|}{ Apnea Test markers } \\
\hline Duration of AT, (minute) & $388(365-411)$ \\
\hline AHI $\left(h^{-1}\right)$ & $21.5(16-29)$ \\
\hline $\min -\mathrm{SpO}_{2}(\%)$ & $78(74-83)$ \\
\hline Duration of $\mathrm{SpO}_{2} \leq 90 \%$ (minute) & $132.5(73-168)$ \\
\hline $\mathrm{NH} \%(\%)$ & $33.2(18-43.9)$ \\
\hline min-HR & $58(52-66)$ \\
\hline $\max -\mathrm{HR}$ & $121(102-134)$ \\
\hline
\end{tabular}

Table 2. Comparison of NH\% groups.

\begin{tabular}{|c|c|c|c|}
\hline & $\begin{array}{c}\mathrm{NH} \%<18 \% \\
(\mathrm{n}=16)\end{array}$ & $\begin{array}{c}\text { NH\% } \geq 18 \% \\
(n=48)\end{array}$ & $\mathbf{p}$ \\
\hline Age (year) & $68 \pm 11$ & $71 \pm 10$ & 0.261 \\
\hline Male, n (\%) & $9(56.2)$ & $35(72.9)$ & 0.213 \\
\hline $\mathrm{BMI},\left(\mathrm{kg} \mathrm{m}^{-2}\right)$ & $27.9 \pm 3.5$ & $29 \pm 4.2$ & 0.340 \\
\hline $\mathrm{CCI}$ & $3(2-4)$ & $5(5-6)$ & $<0.001$ \\
\hline APACHE II & $12 \pm 4$ & $21 \pm 6$ & $<0.001$ \\
\hline CPIS & $8(7-9)$ & $7(7-8)$ & 0.349 \\
\hline Duration of SAT, (min.) & $389(365-408)$ & $387(367-418)$ & 0.620 \\
\hline AHI $\left(h^{-1}\right)$ & $16(14-18)$ & $24(18-32)$ & $<0.001$ \\
\hline $\min -\mathrm{SpO}_{2}(\%)$ & $87.5(79-88)$ & $77(73-82)$ & $<0.001$ \\
\hline Duration of $\mathrm{SpO}_{2} \leq 90 \%$ (min.) & $36(28-62)$ & $145.5(122-177)$ & $<0.001$ \\
\hline $\mathrm{NH} \%(\%)$ & $11 \pm 5$ & $41 \pm 16$ & $<0.001$ \\
\hline $\min -\mathrm{HR}$ & $55 \pm 10$ & $59 \pm 10$ & 0.214 \\
\hline $\max -\mathrm{HR}$ & $98 \pm 13$ & $127 \pm 20$ & $<0.001$ \\
\hline The usage of norepinephrine, $\mathrm{n}(\%)$ & $1(6.2)$ & $26(54.2)$ & $<0.001$ \\
\hline IMV requirement, $\mathrm{n}(\%)$ & $1(6.2)$ & $21(43.8)$ & 0.006 \\
\hline The usage of steroid, $\mathrm{n}(\%)$ & $1(6.2)$ & $19(39.6)$ & 0.013 \\
\hline Length of ICU stay, (day) & $3(3-4)$ & $7(6-8)$ & $<0.001$ \\
\hline Length of hospital stay, (day) & $6(6-8)$ & $12(10-14)$ & $<0.001$ \\
\hline
\end{tabular}

AHI: apnea hypopnea index, APACHE II: acute physiology and chronic health evaluation, BMI: body mass index, CCI: charlson comorbidity index, CPIS: clinical pulmonary infection score, HR: heart rate, ICU: intensive care unit, IMV: invasive mechanical ventilation, max: maximum, min: minimum, NH: nocturnal hypoxia, SAT: sleep apnea test. Results were given as mean $( \pm s d)$, percentage and median (interquartiles). 
Table 3. Multivariate linear regression model for length of hospital stay.

\begin{tabular}{|c|c|c|}
\hline & Coefficient $(95 \%$ CI $)$ & $\mathrm{p}$ \\
\hline Age (year) & $-0.05(-0.10 ; 0.01)$ & 0.086 \\
\hline $\mathrm{BMI}\left(\mathrm{kg} \mathrm{m}^{-2}\right)$ & $-0.05(-0.20 ; 0.09)$ & 0.464 \\
\hline $\mathrm{CCI}$ & $0.57(0.11 ; 1.04)$ & 0.015 \\
\hline APACHE II & $0.17(0.08 ; 0.27)$ & $<0.001$ \\
\hline AHI $\left(h^{-1}\right)$ & $0.001(-0.07 ; 0.07)$ & 0.974 \\
\hline $\min -\mathrm{SpO}_{2}(\%)$ & $-0.07(-0.17 ; 0.04)$ & 0.194 \\
\hline $\mathrm{NH} \%$ & $0.06(0.01 ; 0.11)$ & 0.012 \\
\hline
\end{tabular}

AHI: apnea-hypopnea index, APACHE: acute physiology and chronic health evaluation, BMI: body mass index, CCI: charlson comorbidity index, $\mathrm{CI}$ : confidence interval, $\mathrm{min}-\mathrm{SpO}_{2}$ : minimum peripheral oxygen saturation, $\mathrm{NH}$ : nocturnal hypoxia.

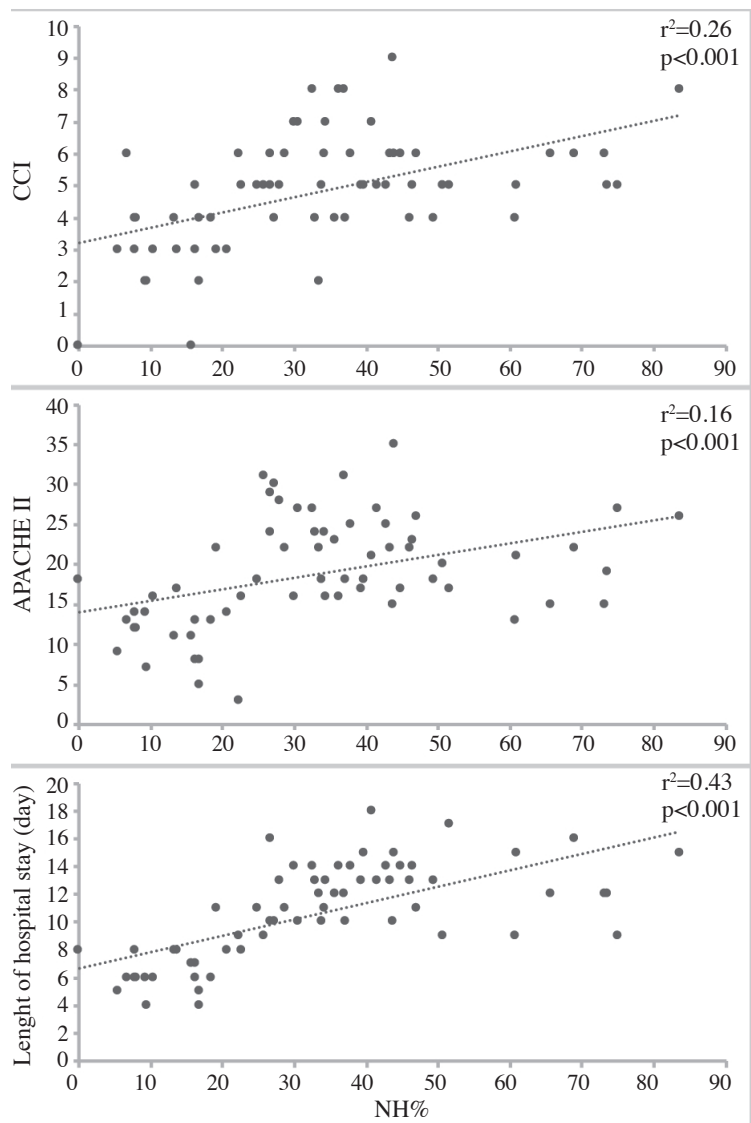

Figure 1. NH\% Correlations.

APACHE II, acute physiology and chronic healt evaluation; CCI, charlson comorbidiy index; $\mathrm{NH}$, nocturnal hypoxia.

result was that median values of $\mathrm{AHI}$ and $\mathrm{NH} \%$ were 21.5 and $33.2 \%$, respectively (Table 1 ). Furthermore, 2 patients with $\mathrm{AHI}<5$ and one patient with $\mathrm{NH} \%=0$ were detected which signifies that the majority of the patients admitted to the ICU had undiagnosed $\mathrm{NH}$ and these patients could be exposed to hypoxia being un- aware of this effect every night before ICU admission. Thus, we can ask this question; "Can ICU admission scores be affected by undiagnosed NH?". It is known that ICU admission scores such as APACHE II help us to predict the likelihood of mortality at the ICU admission ${ }^{[16,17]}$. Li et al. ${ }^{[18]}$ demonstrated that per 5 point increase in APACHE II score was related to risk of death in the ICU. We observed that $\mathrm{NH} \%$ in daily sleep period was positively correlated with APACHE II score and CCI at the ICU admission and also positively correlated with length of hospital stay (Figure 1). Furthermore, when the first quartile of $\mathrm{NH} \%$ was determined as a cut-off value, we observed that ICU admission scores, norepinephrine, steroid and IMV requirements, length of ICU and hospital stays in patients with $\mathrm{NH} \% \geq 18 \%$ were higher than those of the patients with $\mathrm{NH} \%<18 \%$ (Table 2).

In fact, AHI has been suggested to be used as a diagnostic parameter for OSAS in accordance with the Guideline ${ }^{[11]}$. Yet, the different hypoxia definitions in OSAS have been still discussed ${ }^{[19]}$. In the present study, we didn't find any relationship between AHI and each of CCI, APACHE II score and length of hospital stay $\left(\mathrm{r}^{2}=0.04 \mathrm{p}=0.118 ; \mathrm{r}^{2}=0.06 \mathrm{p}=0.068 ; \mathrm{r}^{2}=0.05\right.$ $\mathrm{p}=0.092$ respectively). Therefore, we think that $\mathrm{NH} \%$ may be a better parameter than AHI to define the $\mathrm{NH}$ because $\mathrm{NH}$ can be directly demonstrated.

BMI is expectedly related to worse outcomes, on the contrary there are some studies which had obtained different results ${ }^{[20,21]}$. Onal et al. ${ }^{[22]}$ found a negative correlation between BMI and outcomes. Yang et al. ${ }^{[23]}$ demonstrated that CCI was also a predictive factor for mortality. We also found that length of hospital stay increased by only increases in APACHE II, CCI and NH\% (Table 3). Furthermore, there was not any correlation between $\mathrm{NH} \%$ and $\mathrm{BMI}\left(\mathrm{r}^{2}=0.002 \mathrm{p}=0.738\right)$. If these results can be accepted as evidence for the effects of NH on critically ill patients, then it can be concluded that the patient with worse clinical status at the ICU admission can have undiagnosed $\mathrm{NH}$ and they should be also treated after hospital discharge.

\section{CONCLUSION}

Most of the admitted patients to the ICU can have undiagnosed $\mathrm{NH}$. Increased $\mathrm{NH} \%$ in daily sleep period may be a reason for the worse clinical status at 
the ICU admission and increased length of hospital stay. NH\% may be the better parameter than AHI to demonstrate the NH. Determining and treating undiagnosed NH before ICU admission may improve clinical status of the patients at the ICU admission.

\section{Acknowledgement}

The authors thank to Mehmet Berktas for his support in statistical analysis.

\section{Conflict of Interest}

The authors declare that they have no conflict of interest

\section{REFERENCES}

1. Stoner JD, Angelos MG, Clanton TL. Myocardial contractile function during postischemic low-flow reperfusion: critical thresholds of NADH and $\mathrm{O}_{2}$ delivery. Am J Physiol Heart Circ Physiol 2004;286:H375-80. https://doi.org/10.1152/ajpheart.00436.2003

2. Ferrari R. The role of mitochondria in ischemic heart disease. $J$ Cardiovasc Pharmacol 1996;28 Suppl 1:S1-10.

3. Gupta RM, Parvizi J, Hanssen AD, Gay PC. Postoperative complications in patients with obstructive sleep apnea syndrome undergoing hip or knee replacement: a case-control study. Mayo Clin Proc 2001;76:897-905. https://doi.org/10.4065/76.9.897

4. Gami AS, Hodge DO, Herges RM, Olson EJ, Nykodym J, Kara T et al. Obstructive sleep apnea, obesity, and the risk of incident atrial fibrillation. J Am Coll Cardiol 2007;49:565-71. https://doi.org/10.1016/j.jacc.2006.08.060

5. Appleton SL, Vakulin A, Martin SA, Lang CJ, Wittert GA, Taylor AW et al. Hypertension is associated with undiagnosed obstructive sleep apnea during rapid eye movement (REM) sleep. Chest 2016.

https://doi.org/10.1016/j.chest.2016.03.010

6. Appleton SL, Vakulin A, Wittert GA, Martin SA, Grant JF, Taylor AW et al. The association of obstructive sleep apnea (OSA) and nocturnal hypoxemia with the development of abnormal $\mathrm{HbA} 1 \mathrm{c}$ in a population cohort of men without diabetes. Diabetes Res Clin Pract 2016;114:151-9. https://doi.org/10.1016/j.diabres.2015.12.007

7. Selim BJ, Koo BB, Qin L, Jeon S, Won C, Redeker NS et al. The Association between nocturnal cardiac arrhythmias and sleep-disordered breathing: The DREAM Study. J Clin Sleep Med 2016;12:829-37.

https://doi.org/10.5664/jcsm.5880

8. Hui $\mathbf{P}$, Zhao L, Xie Y, Wei X, Ma W, Wang J et al. Nocturnal hypoxemia causes hyperglycemia in patients with obstructive sleep apnea and type 2 diabetes mellitus. Am J Med Sci 2016;351:160-8.

https://doi.org/10.1016/j.amjms.2015.12.002

9. Yoshida T, Kuwabara M, Hoshide S, Kario K. Recurrence of stroke caused by nocturnal hypoxia-induced blood pressure surge in a young adult male with severe obstructive sleep apnea syndrome. J Am Soc Hypertens 2016;10:201-4. https://doi.org/10.1016/j.jash.2016.01.013

10. Young T, Peppard PE, Gottlieb DJ. Epidemiology of obstructive sleep apnea: a population health perspective. Am J Respir Crit Care Med 2002;165:1217-39. https://doi.org/10.1164/rcem.2109080

11. Epstein LJ, Kristo D, Strollo PJ, Jr., Friedman N, Malhotra A, Patil SP, et al. Clinical guideline for the evaluation, management and long-term care of obstructive sleep apnea in adults. $J$ Clin Sleep Med 2009;5:263-76.

12. Wang Y, Teschler T, Weinreich G, Hess S, Wessendorf TE, Teschler H. Validation of microMESAM as screening device for sleep disordered breathing. Pneumologie 2003;57:734-40. https://doi.org/10.1055/s-2003-812423

13. Gucyetmez B, Atalan HK. Apnea-hypopnea index use among intensive care patients: a case series. J Med Case Rep 2014;8:181. https://doi.org/10.1186/1752-1947-8-181

14. Shoemaker WC. What should be monitored? The past, present, and future of physiological monitoring. Clin Chem 1990;36:1536-43.

15. January CT, Wann LS, Alpert JS, Calkins H, Cigarroa JE, Cleveland JC, Jr. et al. 2014 AHA/ACC/HRS guideline for the management of patients with atrial fibrillation: a report of the American College of Cardiology/American Heart Association Task Force on Practice Guidelines and the Heart Rhythm Society. J Am Coll Cardiol 2014;64:e1-76. https://doi.org/10.1016/j.jacc.2014.03.022

16. Naqvi IH, Mahmood K, Ziaullaha S, Kashif SM, Sharif A. Better prognostic marker in ICU - APACHE II, SOFA or SAP II! Pak J Med Sci 2016;32:1146-51. https://doi.org/10.12669/pjms.325.10080

17. Godinjak A, Iglica A, Rama A, Tancica I, Jusufovic S, Ajanovic A, et al. Predictive value of SAPS II and APACHE II scoring systems for patient outcome in a medical intensive care unit. Acta Med Acad 2016;45:97-103. https://doi.org/10.5644/ama2006-124.165

18. Li G, Cook DJ, Thabane L, Friedrich JO, Crozier TM, Muscedere $\mathbf{J}$ et al. Risk factors for mortality in patients admitted to intensive care units with pneumonia. Respir Res 2016;17:80. https://doi.org/10.1186/s12931-016-0397-5

19. Campos-Rodriguez F, Martinez-Garcia MA, Reyes-Nunez N, Selma-Ferrer MJ, Punjabi NM, Farre R. Impact of different hypopnea definitions on obstructive sleep apnea severity and cardiovascular mortality risk in women and elderly individuals. Sleep Med 2016;27-28:54-8.

https://doi.org/10.1016/j.sleep.2016.05.020

20. Garrouste-Orgeas $M$, Troche G, Azoulay E, Caubel A, de Lassence A, Cheval $\mathbf{C}$ et al. Body mass index. An additional prognostic factor in ICU patients. Intensive Care Med 2004;30:437-43. https://doi.org/10.1007/s00134-003-2095-2

21. Bisurgi G, Caroleo S, Pezzi M, Vero R, Verre M, Amantea B. Obesity and outcomes in the ICU: an observational study. Clin Ter 2010; 161:505-9.

22. Onal O, Ozgun G. Comparison of the course and prognosis of geriatric patients admitted to the intensive care unit according to BMI and albumin values. Anesth Pain Med 2016;6:e32509. https://doi.org/10.5812/aapm.32509

23. Yang M, Mehta HB, Bali V, Gupta P, Wang X, Johnson ML et al. Which risk-adjustment index performs better in predicting 30-day mortality? A systematic review and meta-analysis. J Eval Clin Pract 2015; 21:292-9.

https://doi.org/10.1111/jep.12307 